\title{
ANALISIS KESALAHAN PENGGUNAAN JODOUSHI (VERBA BANTU) YOU DAN RASHII PADA MAHASISWA TINGKAT III PENDIDIKAN BAHASA JEPANG UNDIKSHA
}

\author{
P.R.P.Kumara ${ }^{1}$, I. W. Sadyana², G.S.Hermawan ${ }^{3}$ \\ 123 Jurusan Pendidikan Bahasa Jepang, Universitas Pendidikan Ganesha, Singaraja,Bali \\ e-mail: kumara.narumi@gmail.com, wayan.sadyana@undiksha.ac.id, \\ satya.hermawan@undiksha.ac.id
}

\begin{abstract}
Abstrak
Tujuan dari penelitian ini adalah untuk mendeskripsikan kesalahan mahasiswa tingkat III pendidikan bahasa Jepang Undiksha mengenai penggunaan verba bantu $\sim$ you dan rashii. Penelitian ini merupakan penelitian deskriptif kuantitatif. Subjek penelitian adalah mahasiswa tingkat III jurusan Pendidikan Bahasa Jepang Undiksha. Data dikumpulkan melalui kuesioner dan instrumen tes. Analisis data menggunakan metode analisis data deskriptif kuantitatif. Hasil penelitian ini menunjukkan bahwa rata-rata kesalahan pemakaian verba bantu you dan rashii oleh mahasiswa adalah sebesar 53,64, yang menunjukkan hasil 'cukup'. Dari hasil penelitian, kesalahan pada verba bantu you dengan fungsi sebagai hiyu adalah yang paling dominan dilakukan oleh mahasiswa. Sedangkan kesalahan paling sedikit terjadi pada verba bantu you dengan fungsi sebagai reiji. Kesalahan yang terjadi pada mahasiswa adalah kesalahan karena adanya faktor interferensi, kemudian mahasiswa hanya memperhatikan makna secara leksikal dan kurang memperhatikan konteks kalimat secara keseluruhan.
\end{abstract}

Kata-kata kunci: Analisis kesalahan, verba bantu, you, rashii

\section{要旨}

\begin{abstract}
本研究の目的はガネシャ教育大学、日本語教育学科三年生によける助動詞「よう」
と「らしい」の誤用を明らかにすることである。本研究は記述的な量的である。対 象は日本語教育学科三年生である。データは試験により収集し、定量的記述法で分 析を行った。結果は大学生による「よう」と「らしい」という助動詞の使用の平均 エラー率は５３．６４であり「まあまあ」カテゴリーを示している。データの結果 より、両者の誤用からいうと「比喻」という機能の「よう」の助動詞が最も多く、 そして、「例示」という機能の「よう」の助動詞は最も少ないと達しておる。誤用 の要因は母語、「よう」と「らしい」に語彙的意味のみ注意し、文脈に関する全般 的な意味に不注意と考えられる。
\end{abstract}

キーワード : エラー分析、助動詞、〜よう、〜らしい

\section{Pendahuluan}

Bahasa Jepang merupakan bahasa yang memiliki keunikan terutama dalam hal gramatika. Gramatika bahasa Jepang terdapat sepuluh kelas kata, yaitu doushi atau verba, ikeiyoushi atau ajektiva-i, na-keiyoushi atau ajektiva-na, meishi atau nomina, rentaishi atau prenomina, fukushi atau adverbia, kandoushi atau interjeksi, setsuzokushi atau konjungsi, jodoushi atau verba bantu dan joshi atau partikel. Sebagai pembelajar bahasa asing, khususnya pembelajar bahasa Jepang, tentu pembelajar harus memahami atau setidaknya menguasai kelas kata tersebut. 
Berbicara mengenai kelas kata dalam bahasa Jepang, salah satu kelas kata yang perlu dikuasai oleh pembelajar bahasa Jepang adalah jodoushi. Menurut Hasanudin dkk. (2009:772), bahasa Indonesia tidak memiliki kata kerja bantu, namun hanya memiliki modals, atau modalitas. Berbeda dengan bahasa Jepang yang memiliki kata kerja bantu, sehingga tidak jarang bagi pembelajar bahasa Jepang terutama pembelajar pemula akan mengalami kendala dalam mempelajari atau memahami jodoushi tersebut dan tentu akan mengalami kesulitan ketika dalam menggunakannya dalam kalimat bahasa Jepang. Sehingga tidak sedikit pembelajar bahasa Jepang melakukan kesalahan dalam menggunakan beberapa verba bantu dalam kalimat.

Jodoushi merupakan salah satu kelas kata dalam bahasa Jepang. Jodoushi termasuk pada kelompok fuzokugo, yaitu kata-kata yang tidak dapat berdiri sendiri sebagai kalimat atau frase. Secara singkat dijelaskan bahwa yang dimaksud dengan jodoushi atau verba bantu merupakan kata yang dipakai untuk menerangkan verba dalam frasa verba, biasanya untuk menandai modus, kala atau aspek Sudjianto (2004:149). Sebuah jodoushi dapat memiliki makna apabila menyertai suatu kata, baik verba, nomina, ajektiva, ataupun kata yang lainnya. Selain itu, setiap jenis jodoushi memiliki fungsi yang berbeda. Kata-kata yang termasuk jodoshi dapat menyatakan maksud atau kehendak pembicara dan dapat menambah arti kata yang ada sebelumnya (Yasuo, 1985:193). Contoh dari jodoushi atau verba bantu dalam bahasa Jepang antara lain saseru/seru, nai atau nu, reru/rareru kemudian $\sim$ you, dan $\sim$ rashii, lalu $\sim$ da/desu dan sebagainya, yang secara keseluruhan terdapat 18 jenis verba bantu, Sudjianto, (1999;126-139).

Berbicara mengenai verba bantu, salah satu verba bantu atau jodoushi yang sering menjadi masalah dalam mempelajari bahasa Jepang adalah, verba bantu you dan rashii, karena verba bantu you dan rashii memiliki arti yang mirip atau identical meaning yang dapat diterjemahkan 'nampaknya', 'seperti...' atau 'sepertinya' bila diterjemahkan dalam bahasa Indonesia. Tidak sedikit dari pembelajar bahasa Jepang menganggap bahwa kedua verba bantu tersebut adalah sama atau bahkan bisa saling menggantikan. Namun, dalam bahasa Jepang, kedua verba bantu tersebut memiliki makna dan fungsi masing-masing yang berbeda dan digunakan berdasarkan situasi atau konteks yang mengiringinya. Sehingga, tidak jarang pembelajar bahasa Jepang mengalami kesalahan dalam menggunakan verba bantu you dan rashii tersebut sehingga verba bantu yang seharusnya menggunakan you menjadi tertukar dengan rashii begitu juga sebaliknya.

Demikian halnya seperti yang dialami oleh mahasiswa tingkat III pendidikan bahasa Jepang Undiksha. Mahasiswa tingkat III pendidikan bahasa Jepang Undiksha telah mempelajari verba bantu termasuk you dan rashii dalam mata kuliah tata bahasa atau bunpou sehingga kesalahan dalam penggunaan you dan rashii tidak seharusnya terjadi. Berdasarkan hasil observasi dan angket (yobichousa) yang telah dilakukan kepada mahasiswa tingkat III pendidikan bahasa Jepang Undiksha, dengan pertimbangan bahwa mahasiswa tingkat III tersebut sudah mempelajari bahasa Jepang dasar termasuk jodoushi, baik perubahan bentuk kata kerja, penggunaan kata hubung, dan penggunaan verba bantu. Namun, berdasarkan hasil dari angket atau kuesioner menunjukkan bahwa sebanyak 36 dari 45 mahasiswa tingkat 3 pendidikan bahasa Jepang Undiksha mengalami kesulitan atau belum bisa memahami perbedaan verba bantu antara you dan rashii karena mahasiswa tersebut masih belum mengetahui fungsi dari kedua verba bantu tersebut.

Masalah yang diangkat dalam penelitian ini adalah apa saja kesalahan yang dilakukan oleh mahasiswa pendidikan bahasa Jepang tingkat III Undiksha dalam penggunaan verba bantu you dan rashii dan apa saja faktor penyebab kesalahan penggunaan jodoushi dalam kalimat bahasa Jepang oleh mahasiswa pendidikan bahasa Jepang tingkat III Undiksha

Dalam proses pembelajaran bahasa, kesalahan berbahasa merupakan hal yang biasa terjadi, karena melakukan kesalahan sendiri merupakan salah satu bagian dari proses belajar bahasa itu sendiri. Terlebih jika yang dipelajari adalah B2 atau bahasa asing khususnya bahasa Jepang.

Dulay (1982) (dalam Tarigan, 1988:272) mengatakan, 'kesalahan adalah bagian konversasi atau komposisi yang menyimpang dari beberapa norma baku atau norma terpilih 
dari performansi bahasa orang dewasa. Istilah "kesalahan" yang dipergunakan adalah padanan kata "errors" dalam bahasa Inggris. Dalam bahasa Inggris sendiri kata errors mempunyai sinonim, antara lain: mistakes dan goofs. Demikian pula dalam bahasa Indonesia, disamping kata kesalahan kita pun mengenal kata kekeliruan dan kegagalan.'

Telah disinggung sebelumnya bahwa setiap orang yang sedang belajar bahasa ke dua pasti mengalami kesalahan dalam proses pembelajaranya, hal ini sesuai dengan pendapat Pranowo (1996:51) yang mengatakan bahwa bahasa antara merupakan bahasa yang dihasilkan oleh seseorang yang sedang dalam proses menguasai bahasa ke dua. Ciri utama bahasa antara (interlanguage) adalah adanya penyimpangan struktur lahir dalam bentuk kesalahan (errors) berbahasa. Kesalahan-kesalahan ini bersifat sistematis dan terjadi pada setiap orang yang berusaha menguasai bahasa ke dua. Kesalahan-kesalahan yang dilakukan oleh pembelajar perlu dilakukan analisis kesalahan berbahasa, analisis tersebut bertujuan untuk membantu pembelajar dalam memahami materi dan mengurangi kesalahan yang terjadi.

Jodoushi adalah jika diterjemahkan dalam bahasa Indonesia adalah kata kerja bantu, yang secara linguistik disebut verba bantu. Istilah jodoshi dalam huruf kanji 'jo' berarti bantu atau menolong, kanji 'doushi' dapat berarti verba atau kata kerja. Atau yang dalam bahasa inggris disebut auxiliary verb.

Jodoushi termasuk pada kelompok fuzokugo, yaitu kata-kata yang tidak dapat berdiri sendiri sebagai kalimat atau frase. Jodoushi dapat mengalami perubahan dan dipakai setelah nomina, verba, adjektiva-i, adjektiva-na, dan sebagainya yang disebut katsuyou ga aru. Kata-kata yang termasuk jodoshi dapat menyatakan maksud atau kehendak pembicara dan dapat menambah arti kata yang ada sebelumnya (Yasuo, 1985:193). Salah satu bentuk dari jodoushi adalah you dan rashii. Menurut Tanomura (2007:1) rashii dan you merupakan salah satu bentuk dari jodoushi yaitu kata kerja bantu. Dalam bahasa indonesia rashii dan you dapat diartikan sebagai 'seperti', 'sepertinya' atau katanya'. Walaupun seperti itu, terdapat perbedaan antara rashii dan you dari segi pembentukan kalimat serta pemakaiannya.

\section{Metode}

Penelitian ini menggunakan instrumen penelitian berupa tes. Dalam pengumpulan data, digunakan metode simak, yang mana dalam hal ini melihat hasil dari tes dari mahasiswa mengenai penggunaan verba bantu you dan rashii untuk memperoleh data yang akan diteliti. Kemudian dilanjutkan dengan teknik catat yaitu mencatat data yang ditemukan pada data dan dilanjutkan dengan pengklasifikasian data yaitu membedakan verba bantu you dan rashii yang mengalami kesalahan berdasarkan fungsi dari $\sim$ you dan $\sim$ rashii. Tahaptahap yang dilakukan dalam pengumpulan data pada penelitian ini adalah tahap persiapan, tahap pelaksanaan dan tahap penyimpulan.

Sridhar dalam Tarigan (1995:69) mengemukakan bahwa Analisis kesalahan mempunyai langkah-langkah yang meliputi: 1) Pengumpulan sampel 2) Pengidentifikasian kesalahan 3) Penjelasan kesalahan 4) Pengklasifikasian kesalahan 5) Pengevaluasian kesalahan.

\section{Hasil dan Pembahasan}

Dari hasil data mengenai pemakaian verba bantu you dan rashii dengan instrumen tes yang telah dilakukan terhadap 45 responden, yaitu mahasiswa tingkat III atau angkatan 2015 Undiksha, dapat diketahui bahwa mahasiswa tersebut masih mengalami kesalahan dalam pemakaian verba bantu you dan rashii. Setelah data terkumpul, didapatkan hasil bahwa nilai responden memiliki nilai rata-rata sebesar 53,64, dengan nilai tertinggi sebesar 64 dan nilai terendah sebesar 40 . Hal ini menunjukkan bahwa masih terdapat mahasiswa yang belum memahami pemakaian antara verba bantu you dan rashii karena nilai yang diperoleh oleh mahasiswa tingkat III masih cukup rendah.

Berdasarkan penghitungan, diketahui bahwa rata-rata nilai kesalahan pemakaian verba bantu you dan rashii oleh responden adalah sebesar 53,64. Hasil tersebut menunjukkan tingkat kesalahan mahasiswa dalam menggunakan verba bantu you dan $\sim$ rashii adalah masih dalam kategori cukup. 


\section{Kesalahan verba bantu you dengan fungsi sebagai hiyu}

Pada verba bantu yang pertama adalah verba bantu you dengan fungsi sebagai sebagai hiyu (simile, metaphor) yaitu digunakan untuk mengungkapkan suatu perumpamaan terhadap satu hal dengan hal yang lainnya. Pada verba bantu you sebagai hiyu adalah kesalahan terbanyak yang dilakukan oleh mahasiswa. Kesalahan yang paling tinggi terdapat pada dua butir soal, yakni data soal nomor 2 dan 35. Dari kedua data soal tersebut, prosentase tingkat kesalahan mencapai $100 \%$ atau keseluruhan dari responden mengalami kesalahan. Hal tersebut dapat dilihat pada contoh data soal berikut.

$$
\text { A. 木村： かのじょ, 彼女は日本人じゃないのに、かんじ , 漢字がよく }
$$

Kimura : kanojo wa nihon jin janai noni, kanji ga yoku yomemasune.

(Kimura : dia (wanita) walaupun bukan orang Jepang namun dia bisa membaca kanji dengan baik ya.)

山田：そうですね。日本人（のよう/らしい）ですね。

Yamada : Sou desu ne. nihon jin no you desu ne.

(Yamada : Benar. Sungguh seperti orang Jepang.)

B. たかはし 高橋：ジョニさんは日本語がよく訳話せますね。日本人（のよう/らしい

Takahashi : Joni san wa nihon go ga yoku hanasemasu ne. Nihon jin no you desu ne.

(takahashi : joni san pandai ya berbicara bahasa Jepang. Seperti orang Jepang saja.

ジョニ：いいえ、まだまだです。

Joni : iie mada mada desu.

(Joni : : tidak, saya masih perlu banyak belajar.)

Pada kedua soal A dan B tersebut memiliki konteks yang sama, yakni verba bantu ryou dengan fungsi untuk mengungkapkan perumpamaan yang mana mengumpamakan antara dua hal yang berbeda (hiyu). Untuk data soal A yang pertama, hal yang diumpamakan adalah 'dia' (kanojo) yang bukan orang Jepang (nihon jin janai) diumpamakan dengan 'orang Jepang' (nihon jin) pada umumnya yang bisa membaca huruf kanji dengan baik. Pada soal tersebut dapat diketahui bahwa verba bantu rashii tidak dapat dipakai dalam soal tersebut karena verba bantu rashii tidak lazim dipakai untuk memberikan perumpamaan terhadap dua hal yang berbeda. Begitu juga dengan data soal $B$ yang kedua, pada data soal B 'Joni' yang bukan merupakan orang Jepang diumpamakan dengan layaknya orang Jepang pada umumnya karena kemampuannya berbicara bahasa Jepang (nihon go ga yoku hanasemasu ne). Jadi, verba rashii juga tidak dapat dipakai atau tidak lazim digunakan pada data soal $\mathrm{B}$.

Pada kedua data soal A dan B tersebut, kesalahan dapat terjadi karena adanya pengaruh perbedaan kedua bahasa (bahasa Jepang dengan bahasa Indonesia) dimana mahasiswa terpengaruh bahasa yang lebih dulu dikuasainya atau yang disebut interferensi atau overgeneralization. Seperti yang diketahui, tidak seperti bahasa Jepang, penggunaan kata 'sepertinya' dalam bahasa Indonesia tidak memiliki penggunaan khusus pada suatu kalimat. Artinya, dalam bahasa Indonesia, apabila melihat orang Jepang maupun orang Indonesia asli bisa membaca huruf kanji dengan baik ataupun berbicara bahasa Jepang dengan baik, maka tidak akan jadi masalah apabila menggunakan kata 'sepertinya'. Berbeda halnya dengan bahasa Jepang, yang tentu mengenal adanya perbedaan penggunaan spesifik antara you maupun rashii tergantung dari konteks dan situasinya. Disamping itu, kesalahan dapat terjadi karena mahasiswa sudah terbiasa dengan pola kalimat 'nihon jin (K.Benda) + rashir. Hal ini disebabkan karena pola kalimat tersebut lebih sering muncul atau digunakan dalam pembelajaran terutama kata 'nihon jin' yang diikuti oleh rashii tanpa 
memperhatikan konteks dari soal tersebut. Konteks yang dimaksud yakni seseorang yang bukan orang Jepang diumpamakan dengan orang Jepang yang sebenrarnya. Bila melihat dari pola kalimat secara keseluruhan, pola kalimat tersebut merupakan pola kalimat yang sudah sering dipelajari dalam bahasa Jepang terutama pada mahasiswa tingkat III. Mahasiswa menganggap bahwa dengan melihat kata 'nihon jin' yang merupakan K.Benda, akan tepat bila diikuti oleh rashii, tanpa memperhatikan konteks keseluruhan seperti pada data soal A yakni 'dia' (kanojo) yang bukan orang Jepang yang dibandingkan dengan orang Jepang pada umumnya.

Kemudian, selain dari dua butir data soal A dan B tersebut, kesalahan verba bantu ryou sebagai hiyu, juga terjadi pada data soal yang lain, seperti pada data soal berikut.

C. この ${ }^{\text {みずうみ }}$,湖はおお ${ }^{\text {おきくて、まるでうみ }}$, 海（のよう/らしい）です。

Kono mizuumi wa ookikute, marude umi no you desu.

(Danau ini luas ya, seperti lautan saja).

Pada data soal $\mathrm{C}$ tersebut, meskipun memiliki jenis yang sama dengan data sial $\mathrm{A}$ dan $\mathrm{B}$ yakni verba vantu you sebagai hiyu, kesalahan yang dilakukan oleh responden tidak sebesar data soal A dan B, yakni hanya sebesar $28,8 \%$. Hal tersebut dikarenakan sebagian besar dari responden telah mampu melihat konteks bahwa mizuumi (danau) dan umi (lautan) merupakan dua hal yang berbeda sehingga verba bantu rashii tidak lazim digunakan pada data soal $\mathrm{C}$ tersebut. Pada data soal C, kesalahan yang dilakukan oleh sebagian kecil responden dikarenakan responden tidak melihat konteks secara teliti sehingga mengabaikan kata mizuumi (danau) dan umi (lautan) sebagai dua hal yang berbeda yang seharusnya dijadikan acuan dalam menjawab soal tersebut. Kedua hal dari data soal C tersebut (danau dan lautan) merupakan dua hal yang berbeda dan menjadi kata kunci dalam data soal tersebut, sebab apabila ingin memberikan perumpamaan atau mengibaratkan suatu hal satu dengan hal yang lainnya yang berbeda, maka verba bantu yang digunakan adalah $~ y o u$ sesuai dengan fungsinya sebagai hiyu (simile, metaphor). Disamping itu, kesalahan juga dapat terjadi karena factor interferensi atau kalimat tersebut dimaknai ke dalam bahasa Indonesia oleh responden sehingga bila data soal A tersebut diterjemahkan dalam bahasa Indonesia, akan menjadi 'Danau ini luas ya, seperti lautan saja'. Kata 'seperti' pada kalimat tersebut, memiliki kemiripan arti dengan you dan rashii, sehingga dengan adanya kemiripan pada kata tersebut, mengakibatkan terjadinya kesalahan pada responden.

Ketiga data soal A, B dan C tersebut sama-sama merupakan data soal verba bantu you dengan fungsi sebagai hiyu. Namun demikian, tingkat kesalahan responden pada data soal A dan B jauh lebih tinggi dari data soal verba bantu sejenisnya, dalam hal ini diwakilkan oleh data soal C. Hal tersebut terjadi karena pemahaman konteks pada soal. Seperti yang dijelaskan sebelumnya bahwa kesalahan yang terjadi pada data soal A dan B tersebut terjadi karena responden sudah terkonsep menggunakan pola kalimat 'nihon jin (K.Benda) + rashi'. $\mathrm{Hal}$ ini disebabkan karena pola kalimat tersebut lebih sering muncul atau digunakan dalam pembelajaran terutama kata 'nihon jin' yang selalu diikuti oleh rashii tanpa memperhatikan konteks dari soal tersebut. Bila melihat data soal $\mathrm{C}$ hal ini menunjukkan bahwa sebagian besar responden memahami bahwa verba bantu you digunakan untuk memberikan perumpamaan terhadap dua hal yang berbeda misalnya mizuumi (danau) dengan umi (laut), namun kebanyakan dari responden belum memahami bahwa perbedaan antara orang Jepang dengan orang Indonesia juga digunakan pada fungsi hiyu tesebut karena dua hal tersebut adalah dua hal yang berbeda.

\section{Verba bantu you dengan fungsi sebagai suiryou}

Kemudian, pada fungsi dari verba bantu you selanjutnya adalah fungsi sebagai suiryou yaitu memberikan suatu dugaan berdasarkan penilaian pribadi (guess). Prosentase kesalahan tertinggi pada verba bantu you sebagai suiryou adalah $62,2 \%$ yang dapat dilihat pada contoh data soal sebagai berikut

D. 田中： ひと,人が たいせい, 大勢 あつ,集まっていますね。 
Tanaka :hito ga oozei atsumatteimasu ne

(Tanaka :banyak orang berkumpul ya)

$$
\begin{aligned}
& \text { 山田：事故がおきた（よう/らしい）ですね。きゅうきゅうしゃ，救急車がき, 来てい } \\
& \text { ますよ。 } \\
& \text { Yamada : jiko ga okita you desu ne. kyuukyuusha ga kiteimasu yo. } \\
& \text { (Yamada : sepertinya terjadi kecelakaan. Ada ambulans yang datang lho) }
\end{aligned}
$$

Pada soal D tersebut, terlihat pada soal tersebut, pembicara kedua (Yamada) memberikan asumsi bahwa tengah terjadi kecelakaan (jiko). Ungkapan tersebut didapat berdasarkan penilaian-penilaian dari adanya kalimat dari pembicara pertama (Tanaka) yang menuturkan 'hito ga oozei atsumatteimasu ne.' (banyak orang yang berkumpul). Kemudian, asumsi tersebut didukung oleh adanya ambulans yang datang, (kyuukyuusha ga kiteimasu yo). Sehingga berdasarkan keadaan atau gejala-gejala tersebut, pembicara kedua (Yamada) membuat asumsi bahwa tengah terjadi kecelakaan. Sehingga sesuai dengan fungsi dari verba bantu you sebagai suiryou.

Pada data soal $D$ tersebut, bahasa ibu atau bahasa Indonesia memberikan pengaruh terhadap responden sehingga terjadi overgeneralization atau kesalahan pada mahasiswa yang menguasai suatu bentuk bahasa yang dipelajari lalu menerapkannya dalam konteks. Dalam bahasa Indonesia, penggunaan kata 'sepertinya' tidak dipengaruhi oleh konteks dalam suatu kalimat. Misalnya seperti pada data soal D, apabila melihat banyak orang berkumpul, maka ketika memberikan asumsi bahwa tengah terjadi kecelakaan akan tetap menggunakan kata 'sepertinya' ('sepertinya' tengah terjadi kecelakaan). Hal ini berbeda dengan bahasa Jepang yang mengenal adanya penggunaan khusus antara $\sim$ you dan $\sim$ rashii yang dipengaruhi oleh konteksnya. Hal tersebut kemudian membuat responden memaknai $\sim$ rashii ke dalam bahasa Indonesia sehingga terjadi kesalahan. Kemudian, disamping adanya pengaruh bahasa ibu atau bahasa Indonesia, kesalahan pada data soal tersebut dikarenakan responden mengabaikan kalimat-kalimat kunci yang menjadi acuan dalam menjawab, seperti pada kalimat dari pembicara pertama (Tanaka) yang menuturkan 'hito ga oozei atsumatteimasu ne' dan kalimat dari pembicara kedua (Yamada) yang menuturkan 'kyuukyuusha ga kiteimasu yo'. Dari kedua kalimat tersebut merupakan penilaian-penilaian untuk mengungkapkan suatu asumsi. Apabila hanya melihat dari kalimat 'hito ga oozei atsumatteimasu ne.' dari pembiacara pertama (Tanaka) tidaklah cukup untuk memberikan asumsi bahwa tengah terjadi kecelakaan karena banyaknya orang berkumpul belum tentu terjadi kecelakaan. Jadi, yang menjadi acuan dalam memberikan suatu asumsi terdapat pada kalimat 'kyuukyuusha ga kiteimasu yo' (ambulans yang datang) dari pembicara kedua (Yamada). Sehingga dari kejadian-kejadian tersebut dapat diberikan asumsi bahwa tengah terjadi kecelakaan (jiko).

Dari contoh data soal tersebut, pada verba bantu you dengan fungsi sebagai suiryou secara keseluruhan dapat diketahui bahwa mahasiwa masih hanya memahami dari segi leksikalnya saja, sehingga terkonsep menggunakan pemahaman leksikal tersebut sebagai acuan untuk menjawab soal. Pemahaman verba bantu you pada fungsi suiryou adalah memberikan suatu dugaan berdasarkan asumsi peribadi dengan penilaian dari keadaan atau gejala-gejala yang terjadi. Namun gejala-gejala tersebut tidaklah hanya satu gejala, melainkan lebih dari satu gejala. Seperti pada data soal $D$ tersebut, gejala-gejala atau keadaan yang dimaksud adalah 'hito ga oozei atsumatteimasu ne.' (banyak orang yang berkumpul), kemudian 'kyuukyuusha ga kiteimasu yo' (ada mobil ambulans yang datang). Sehingga dari gejala-gejala tersebut dapat diberikan asumsi bahwa tengah terjadi kecelakaan.

\section{Verba bantu you dengan fungsi sebagai reiji}

Pada verba bantu berikutnya adalah you pada fungsi sebagai reiji yakni berfungsi untuk memberikan suatu contoh (exemplification). Pada fungsi reiji adalah kesalahan yang paling sedikit dilakukan oleh mahasiswa atau responden dengan tingkat kesalahan tertinggi hanya mencapai $13,3 \%$ yang dapat dilihat pada contoh data soal berikut. 
E. この れい, 例（ のように/らしく） が,書いてください。

kono rei no you ni kaite kudasai

(tulislah seperti contoh ini)

Pada data soal E tersebut adalah jenis data soal dari verba bantu you dengan fungsi sebagai reiji yaitu untuk memberikan contoh pada suatu hal (exemplification), seperti pada data soal tersebut, pada kata 'kono rei' adalah sebuah 'contoh' yang diberikan oleh pembicara, kemudian kata 'kaite kudasa' adalah bentuk imperatif agar menulis sesuai 'contoh' yang diberikan. Verba bantu r rashii tidak lazim digunakan pada kalimat tersebut karena tidak memiliki fungsi sebagai reiji (memberikan contoh terhadap suatu hal). Sehingga, frasa 'kono rei' tidak lazim apabila diikuti oleh verba bantu rashii.

Sebagian besar responden telah berhasil menjawab dengan tepat, meskipun sebagian kecil dari responden belum mampu menjawab dengan tepat. Kesalahan dari sebagian kecil responden dapat terjadi karena pengaruh pemakaian pola kalimat ' $\sim$ rashiku + k.kerja( te) kudasal' yang sering dipelajari oleh responden. Pola kalimat tersebut sering digunakan dan dipelajari oleh responden sehingga dapat menyebabkan responden cenderung menerapkan pola kalimat tersebut tanpa melihat konteks kalimat secara keseluruhan. Disamping itu, adanya pengaruh bahasa ibu juga dapat menyebabkan terjadinya kesalahan. Dalam bahasa Indonesia apabila akan mengungkapkan pemberian contoh terhadap suatu hal (seperti pada data soal E), tetap akan menggunakan kata 'seperti'. Seperti halnya pada data soal tersebut, bila diterjemahkan dalam bahasa Indonesia, akan menjadi 'tulislah seperti contoh ini'. Hal tersebut tentu akan membingungkan bagi responden sebab situasi dan konteks dalam kalimat akan menjadi hal yang menentukan pemakaian dalam penggunaan verba bantu you dan $\sim$ rashii.

Kemudian, berbeda dengan data soal $\mathrm{E}$, dari data soal verba bantu you pada fungsi reiji yang lainnya, tingkat kesalahan yang dilakukan oleh responden pada verba bantu you pada fungsi reiji pada data soal yang lain hanya $0 \%$ atau tidak terdapat responden yang melakukan kesalahan. Hal tersebut terdapat pada data soal berikut.

F. 私はあなた（のような/らしい）人がきらいです。

Watashi wa anata no you na hito ga kirai desu.

(saya benci orang seperti kamu)

Pada data soal $\mathrm{F}$ tersebut, tingkat kesalahan yang dilakukan oleh responden pada data soal tersebut mencapai $0 \%$ atau keseluruhan dari responden mampu menjawab dengan tepat. Hal ini dikarenakan bahwa kalimat secara keseluruhan telah dapat dipahami oleh seluruh responden baik dari segi konteks maupun situasi.

Kedua soal $\mathrm{E}$ dan $\mathrm{F}$ tersebut merupakan dua soal yang sejenis, yakni data soal verba bantu you dengan fungsi sebagai reiji. Meskipun data soal $\mathrm{E}$ dan $\mathrm{F}$ sama-sama merupakan bentuk dari reiji, namun seperti yang dijelsakan sebelumnya, bahwa kesalahan yang terjadi pada data soal E dikarenakan kecenderungan pemakaian pola kalimat ' rashiku + k.kerja( te) kudasai yang sering dipelajari oleh responden sehingga sebagian kecil dari responden menjadi terkonsep dalam menggunakan pola kalimat tersebut dalam menjawab soal sehingga sebagian kecil dari responden mengalami kesalahan.

\section{Verba bantu rashii dengan fungsi sebagai denbun}

Berikutnya yang keempat adalah verba bantu rashii sebagai denbun (hearsay, rumor) yakni digunakan untuk menyampaikan suatu informasi berdasarkan sumber lain. Prosentase kesalahan yang paling tinggi pada verba bantu rashii dengan fungsi sebagai denbun adalah $48,8 \%$ yang dapat dilihat pada data soal berikut. 


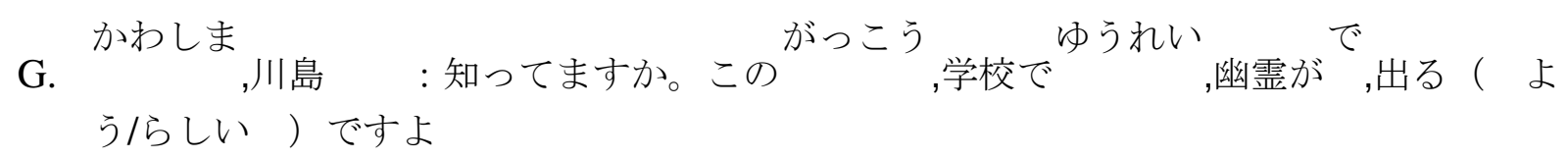

Kawashima: Shittemasuka. Kono gakkou de yuurei ga deru rashii desu yo.

(Kawashima: tahu tidak? Kabarnya di sekolah ini ada hantunya).

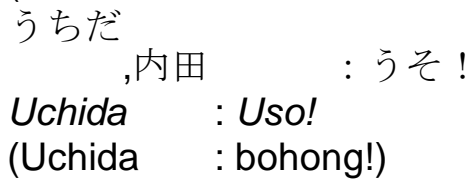

Pada data soal $G$ tersebut, prosentase kesalahan responden mencapai $48,8 \%$. Kesalahan yang dilakukan oleh setengah dari responden dapat terjadi karena dihilangkannya atau tidak disertakannya kata bantu atau kata kunci seperti kata 'uwasa de wa' yang menjadi acuan oleh responden, sehingga memungkinkan responden menjadi kebingungan sehingga melakukan kesalahan. Pada data soal $\mathrm{G}$ tersebut, bila hanya melihat dari kalimat 'Kono gakkou de yuurei ga deru ... desu yo' tentu terdapat responden yang menganggap bahwa kalimat tersebut adalah kalimat untuk memberikan suatu 'dugaan' bahwa di sekolah tersebut berhantu. Namun, bila melihat kalimat dari penutur pertama (Kawashima) secara keseluruhan, kalimat tersebut bukanlah merupakan suatu 'asumsi' atau 'dugaan', namun lebih ke ungkapan untuk menyampaikan informasi ke orang lain, tentu apabila menyampaikan suatu informasi, selalu ada suatu sumber yang menjadi asal mula informasi tersebut. Begitu juga dalam kalimat tersebut, yang mana penutur pertama (Kawashima) menyampaikan suatu informasi kepada penutur kedua (Uchida) bahwa di sekolah mereka berhantu. Tidak disertakannya kata kunci seperti 'uwasa de wa' atau ' no hanashi ni yoru to' dimungkinkan membingungkan bagi responden karena sebagian responden hanya terkonsep dengan makna leksikal atau pengaruh dari bahasa Indonesia yang menjadi acuan dari responden untuk menjawab soal tersebut.

Sedangkan responden yang berhasil menjawab dengan tepat dikarenakan pada soal tersebut, meskipun tidak terdapat kata bantu (uwasa de wa), sebagian dari responden telah memahami bahwa pada soal tersebut memiliki maksud untuk menyampaikan informasi, terlihat dari soal tersebut, pada kalimat 'Kono gakkou de yuurei ga deru ... desu yo' dapat diketahui bahwa penutur pertama (Kawashima) memberikan informasi kepada pembicara kedua (Uchida) bahwa di sekolahnya berhantu. Informasi dari pembicara pertama (Kawashima) tersebut tentu didapat dari berbagai macam sumber baik melalui kabar angin dan lain sebagainya.

Kemudian selain dari butir data soal $\mathrm{G}$ tersebut, kesalahan verba bantu rashii sebagai denbun, juga terjadi pada data soal yang lain, seperti pada data soal berikut.

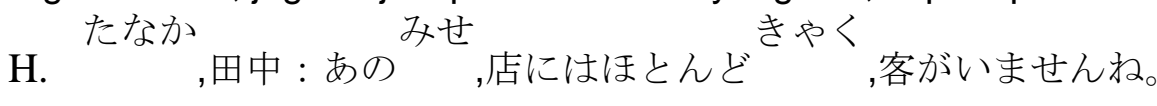

Tanaka :Ano mise wa hotondo kyaku ga imasen ne.

(Tanaka :di toko itu pelanggannya sedikit ya).

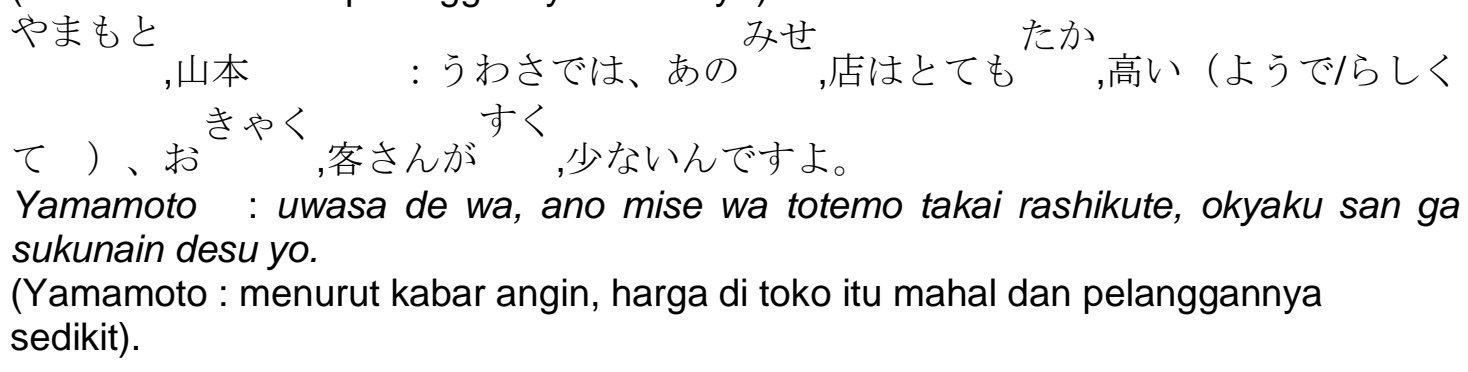

Pada data soal $\mathrm{H}$ tersebut, meskipun memiliki jenis atau fungsi yang sama dengan data soal $\mathrm{G}$ yakni verba bantu rashii dengan fungsi sebagai denbun, namun tingkat kesalahan dari data soal H lebih rendah daripada data soal G, yakni hanya sebesar $40 \%$. Sebagian besar responden mampu menjawab dengan benar hal ini dimungkinkan karena mereka melihat 
adanya kata kunci yang terdapat pada soal, yaitu kata 'uwasa de wa' (menurut kabar angin) yang berarti verba bantu you tidak lazim digunakan.

Kesalahan oleh sebagian kecil mahasiwa dapat terjadi karena mereka mengabaikan kata 'uwasa de wa' yang sesungguhnya menjadi kata kunci dalam menjawab soal tersebut. Pada data soal $\mathrm{H}$ tersebut, kalimat pertama dari pembicara pertama (Tanaka) 'ano mise wa hotondo kyaku ga imasen ne' dimungkinkan menjadi acuan sebagian kecil responden sehingga melakukan kesalahan dengan menjawab you, karena responden menganggap kalimat tersebut adalah ungkapan sebagai 'dugaan', namun, padahal kata kuncinya terdapat pada kalimat dari pembicara kedua (Yamamoto) yang mengungkapkan 'uwasa de wa, ano mise wa totemo takai rashikute, okyaku san ga sukunain desu yo'. Dari kalimat tersebut, kata 'uwasa de wa' merupakan kata kunci dari data soal tersebut. Tentu dapat diketahui bahwa kalimat tersebut merupakan ungkapan untuk menyampaikan kabar atau informasi kepada orang lain berdasarkan sumber tertentu.

Kesalahan dari data soal $\mathrm{G}$ lebih tinggi daripada data soal $\mathrm{H}$, hal ini terjadi dikarenakan tidak disertakannya kata kunci seperti 'uwasa de wa' atau ' no hanashi ni yoru to' hal ini tentu akan membingungkan bagi responden karena sebagian responden hanya terkonsep dengan makna leksikal atau pengaruh dari bahasa Indonesia yang menjadi acuan dari responden untuk menjawab soal tersebut. Padahal tanpa adanya kata bantu tersebut, sudah dapat diketahui bahwa kalimat tersebut merupakan kalimat untuk menyampaikan informasi.

\section{Verba bantu rashii dengan fungsi sebagai hikyou}

Berikutnya yang keempat adalah verba bantu rashii sebagai hikyou (comparion, similitude) digunakan untuk mengungkapkan persamaan tipe atau bagaimana lazimnya suatu hal atau keadaan. Frekuensi kesalahan yang paling tinggi yang dilakukan oleh responden pada verba bantu rashii dengan fungsi sebagai hikyou terjadi pada data soal berikut.

I. 村山：もうすぐ4月になりますね。

Murayama: mou sugu shi gatsu ni narimasu ne.

(Murayama: sebentar lagi bulan april ya).

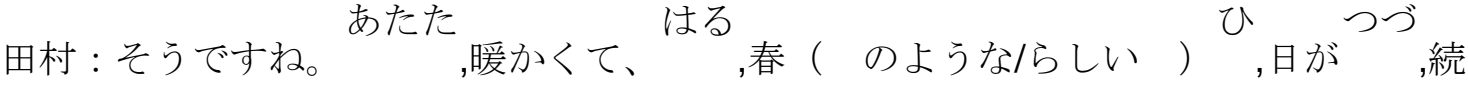

$$
\begin{aligned}
& \text { いていますね。 }
\end{aligned}
$$

Tamura : sou desu ne. atatakakute, haru rashii hi ga tsuzuite imasu ne.

(Tamura : iya. Hari yang hangat khas musim semi akan terus berlanjut).

Pada soal I tersebut, tingkat kesalahan mencapai $80 \%$. Pada verba bantu $\sim$ rashii sebagai hikyou, berfungsi untuk menyamakan atau membandingkan antara dua hal yang sama atau dua hal yang selayaknya hal tersebut. Seperti pada soal tersebut, hal yang dibandingkan adalah suasana yang hangat dari 'haru' atau suasana khas musim semi (selayaknya musim semi) pada bulan april. Sehingga verba bantu you tidak lazim digunakan untuk membandingkan dua hal yang sama.

Pada kalimat tersebut, dari segi pola kalimat, baik pola kalimat K.Benda + rashii (haru rashii) maupun pola kalimat K.Benda + you (haru no you) tidak ada yang salah bila dilihat dari segi tata bahasa, namun yang menentukan adalah konteks dari kalimantya. Dari kalimat tersebut, diketahui yang menjadi perbandingan adalah musim semi 'haru' dengan selayaknya musim semi yang hangat. Pada soal tersebut, kesalahan yang terjadi pada responden dapat terjadi karena soal yang terlalu sulit bagi sebagian besar responden, sehingga responden hanya menggunakan pola kaliamat K.Benda + rashii (haru rashii) yang merupakan pola kalimat yang dipelajari oleh responden sehingga menjadi terkonsep menerapkan pola kalimat tersebut sebagai acuan dalam menjawab data soal tersebut. Hal 
tersebut menjadi salah satu factor yang menyebabkan terjadinya kesalahan selain adanya factor bahasa ibu.

Kemudian selain data soal I tersebut, kesalahan verba bantu rashii sebagai hikyou pada data yang serupa juga terjadi pada data soal berikut.

J. かのじょ, 彼女のかお 顔はおとこ ${ }^{\text {, 男に }}$,見えるが、たいどはおんな（のよう/らし

Kanojo no kao wa otoko ni mieru ga, taido wa onna rashii desu ne.

(Dilihat dari wajahnya dia kelihatan seperti laki-laki namun sikapnya seperti layaknya seorang wanita ya)

Namun, berbeda dengan data soal I, pada data soal $\mathrm{J}$ tingkat kesalahan hanya sebesar $40 \%$. Pada data soal J, seperti yang diketahui bahwa pada verba bantu rashii dengan fungsi sebagai hikyou digunakan apabila mengungkapkan kesamaan atau membandingkan dua hal yang sama atau selayaknya hal tersebut. Terlihat pada kalimat 'Kanojo no kao wa otoko ni mieru ga, taido wa onna ... desu ne'. Pada kalimat tersebut yang disamakan adalah seorang wanita (kanojo) dengan selayaknya seorang wanita itu sendiri dari sisi sikapnya (taido).

Sebagian besar dari mahasiswa telah berhasil menjawab dengan tepat, hal ini dimungkinkan karena sebagian besar responden telah mengetahui bahwa dua hal yang disamakan adalah seorang wanita dengan selayaknya wanita itu sendiri melihat dari sisi sikap (taido). Sedangkan kesalahan yang dilakukan oleh sebagian kecil responden dapat dimungkinkan karena tidak memperhatikan konteks kalimat, yakni kanojo (wanita) yang disamakan dengan selayaknya seorang wanita.

Dari soal I dan $\mathrm{J}$ merupakan soal yang sejenis yakni verba bantu rashii sebagai hikyou. Meskipun demikian, kesalahan pada soal I yang dialami oleh mahasiswa lebih tinggi daripada data soal J. Hal ini disebabkan karena data soal I memiliki tingkat kesukaran yang lebih tinggi daripada data soal J. Seperti pada data soal I hal yang diungkapkan adalah suasana hangat dari haru (suasana khas musim semi) dengan layaknya suasana tersebut. Tentu yang menjadikan banyak mahasiswa yang mengalami kesalahan adalah pola kaliamat K.Benda + rashii (haru rashii) yang merupakan pola kalimat yang dipelajari oleh responden sehingga menjadi terkonsep menerapkan pola kalimat tersebut sebagai acuan dalam menjawab data soal tersebut.

\section{Simpulan dan Saran}

Berdasarkan hasil analisis yang telah dipaparkan, maka dapat ditarik simpulan, yaitu kesalahan yang paling sering dilakukan oleh mahasiswa mengenai pemakaian verba bantu $\sim$ you dan rashii adalah verba bantu you pada fungsi hiyu. Kesalahan mahasiswa dalam penggunaan verba bantu you dan rashii adalah (1) kesalahan karena adanya pengaruh bahasa Indonesia atau yang disebut interferensi karena verba bantu you dan rashii memiliki kemiripan arti dalam bahasa Indonesia (identical meaning) (2) kesalahan karena hanya memerhatikan pola kalimat tertentu tanpa memperhatikan konteks dan situasi yang mengiringi (3) kesalahan dalam memahami konteks kalimat sehingga verba bantu yang digunakan menjadi tertukar.

Dengan adanya penelitian mengenai analisis kesalahan dalam pemakaian verba bantu you dan rashii ini, maka diharapkan pembelajar bahasa khususnya bahasa Jepang memperoleh pengetahuan lebih mengenai perbandingan dari fungsi verba bantu tersebut sehingga bisa berhati-hati untuk menggunakan ungkapan yang memiliki fungsi dan arti sama seperti ungkapan you dan rashii. Selain itu, dengan adanya penelitian ini diharapkan peneliti lainnya bisa mengembangkan lebih lanjut mengenai penggunaan $\sim$ you dan rashii dalam kajian pragmatik sehingga bisa mendapatkan hasil analisis yang lebih dalam dan detail mengenai kedua konjungsi tersebut. 


\section{Daftar Pustaka}

Chaer, Abdul. 2003. Linguistik Umum. Jakarta: PT Rineka Cipta

Dahidi, Ahmad dan Sudjianto. 2004. Pengantar Linguistik Bahasa Jepang. Bekasi Timur: Kesaint Blanc.

W. S., Hasanuddin. 2009. Ensiklopedi Kebahasaan Indonesia. Bandung: Angkasa.

Ichikawa, Y. 2005. Nihongo Goyou Reibun Shoujiten. Tokyo: Bonjinsha

Makino, Seiichi dan Michio Tsutsui. 1989. A Dictionary of Intermediate Japanese Grammar. Japan: The Japan Times.

Mizumoto, T., Ikeda, R., \&. Fukuda. A. 2002. Academic Japanese : 例文で学ぶ助動 (Reibun de manabu Jodoushi) [Academic Japanese: Japanese Expressions Handbook Series 9, Learning Auxiliary Verbs by Example Sentences ]. In M. Sasaki (Ed.). Tokyo: Alc Press.

Moleong, Lexy. J. Metode Penelitian Kualitatif. Bandung: Remaja Rosdakarya. 1989.

McCready, Eric dan Ogata, Norri. 2006. Evidentiality Modality and Probality : Japan: Universitas Osaka

Nurhadi. 2010. Dimensi-dimensi dalam Belajar Bahasa Kedua. Bandung: Sinar Baru Algensindo.

Pateda, Mansoer. 2001. Semantik Leksikal. Edisi Kedua. Cetakan Pertama. Jakarta: Rineka Cipta.

Sudjianto, 1996. Gramatika Bahasa Jepang Modern Seri B. Jakarta: Kesaint Balnc.

Sudaryanto. 1993. Metode dan Aneka Tehnik Analisis Bahasa: Pengantar Penelitian Wahana Kebudayaan secara Linguistik. Yogyakarta: Duta Wacana University Press.

Sugiyono. 2009. Metode Penelitian Pendidikan. Bandung: ALFABETA.

Sutedi, Dedi. 2004. Dasar-dasar Linguistik Bahasa Jepang. Bandung: Humaniora.

Tarigan, H. G. dan Tarigan, D. 1995. Pengajaran Analisis Kesalahan Berbahasa. Bandung: Humaniora.

Tanomura, Tadaharu. 1991. Rashii to yooda no imi no soui ni tsuite (The differences in meaning between rashii and yooda). Gengogaku Kenkyuu (Linguistic Research) 10. $62-78$.

Tim Penyusun. 2007. Kamus Besar Bahasa Indonesia. Jakarta: Balai Pustaka.

Verhaar, M. 2008. Asas-asas Linguistik Umum. Cetakan keenam. Yogyakarta: Gadjah Mada University Press.

Wahyuni, Iis. 2013. "Analisis Kesalahan Kalimat Bahasa Jepang Mahasiswa Sastra Jepang Universitas Brawijaya (Kajian Morfologi dan Sintaksis)". Artikel Ilmiah. Surabaya: Universitas Brawijaya. atics. New York: Oxford University Pres 